\title{
GENERATION OF CRACKS IN HIGHWAY EMBANKMENT ON BLACK COTTON SOIL
}

\author{
Yongzhen Cheng, Yun Dong, Jingke Wu, Baoliang Li and Jihua Zhang \\ Huaiyin Institute of Technology, Faculty of Architecture and Civil Engineering, Huai'an, No.89 \\ Beijing North Road, China; e-mail: dyun@hyit.edu.cn
}

\begin{abstract}
This research revealed the crack generation of the highway embankment from the water losing shrinkage of the wet black cotton soil (BCS), which is a type of soil with high swell-shrink potential. The road seepage meter was used to test the permeability of filling materials, which was used to replace BCS. The moisture content and embankment deflection of BCS foundation were measured after the rainy season. Based on the coupled consolidation theory for unsaturated soil, the change in additional tension stress of the embankment induced by water loss shrinkage of BCS was simulated by Abaqus. The results indicated that the rainfall seeped into the foundation through highly permeable refill materials to result in BCS expansion and decrease the embankment strength. After the rainy season, the additional tensile stress caused by water loss shrinkage of BCS induces cracking of highway embankment, and the maximum cracking depth often appears at the shoulder of highway. The deep and wide cracks are easy to appear in the low embankment constructed on a thick BCS foundation under strong evaporation.
\end{abstract}

\section{KEYWORDS}

Embankment crack, Black cotton soil, Moisture change, Shrinkage, Tension stress

\section{INTRODUCTION}

Black cotton soil (BCS) is discovered in abundance in Ethiopia [1]. BCS is a type of soil with a high expansion when the moisture content in soil changes [2,3]. The swell/shrink behaviour gives rise to serious engineering problems in highway embankment on BCS. A case in point was found in the existing highway connecting the capital Addis Ababa with Adama, where the subgrade strength decreased in the heave rainy season, and the embankment cracks developed in the following dry season. It is to determine out the influence of spatial and boundary conditions on the crack generation to overcome those subgrade diseases.

Replacement of BCS with nonexpansive materials is the main method to overcome the water swelling of BCS in Ethiopia. It is recommended in the design features of the highway to remove the existing BCS up to a depth of 0.6-1.8 $\mathrm{m}$ and replace it with selected suitable materials up to the bottom of the sub-base layer. The depth of the excavation is determined in accordance with the plasticity index and the volume of traffic. In some researches, the active zone of BCS was measured as an evaluation index to determine the depth of the excavation. As the moisture content remains stable, BCS below the active zone has a small influence on the upper highway embankment. The depth of the excavation can be determined with the help of the classification of BCS [4-6]. Unfortunately, the subgrade cracks occurred in the highway connecting the capital Addis Ababa with Adama, where the BCS was excavated and replaced by gravel soil or the mixes of clay and scoria [7]. 
Addis Ababa - Adama highway in Ethiopia, which was implemented by a design and research institute in China, developed many cracks in the embankment after a heavy rainy season. This research reveals the causation of crack in highway embankment, using the field experiment and numerical simulation. The moisture change of BCS at the different depth was measured by drilling and sampling. The permeability test was performed on the replacement materials. The deflection was also measured on the highway embankment with and without cracks. The increase in moisture content was determined in the BCS after the rainy season. Nevertheless, the cracks were generally found in the highway embankment with a height of less than $1.75 \mathrm{~m}$. The slope instability due to rainfall infiltration rarely happens in such a low embankment. Hence, subgrade cracks should occur in the process of soil surface evaporation after a heavy rain. On the basis of the coupled consolidation theory for unsaturated soil, BCS shrinkage due to water loss was simulated by Abaqus/Standard to obtain the stress distribution in highway embankment, starting with the wet status of subgrade after a heavy rainy season.

\section{THE STUDY SITE}

\section{Rainfall and evaporation at Ethiopia}

Ethiopia is situated in the tropics, but most regions of the country are milder due to the high terrain. The heavy rainy season starts in June with the coming of the southwest monsoons and continues till September. The dry season lasts from October to January of the next year. The months from February to May constitute the light rainy season. The region of plateau gets about $1,000-1,500 \mathrm{~mm}$ rainfall per year, but it reduces to $250-500 \mathrm{~mm}$ in the lowland. Evaporation intensity can be modelled for soil-atmosphere interaction problems by the meteorological data [8]. Here FAO 56 PM model was employed to calculate the evaporation intensity in Ethiopia, using the air temperature, dew point temperature and wind speed $[9,10]$. The evaporation intensity ranges from $3.11 \times 10^{-8} \mathrm{~m} / \mathrm{s}$ to $7.25 \times 10^{-8} \mathrm{~m} / \mathrm{s}$ in the most region of Ethiopia.

\section{Soil stratification}

A total of twelve boreholes were drilled along the existing motorway route connecting the capital Addis Ababa with Adama. The thickness of BCS ranges from $0.5 \mathrm{~m}$ to $3.2 \mathrm{~m}$. The properties of BCS obtained according the Chinese standards [11] are presented in Table 1. The grain analysis was performed on BCS samples by the transfer pipette. The clay content in the BCS is between $45 \%$ and $51 \%$, and the silt content is between $49 \%$ and $55 \%$. The liquid limit of BCS ranges from $68.5 \%$ to $73.8 \%$, and the plasticity index ranges from $31.6 \%$ to $37.2 \%$. All soil samples plot on the right of ' $B$ ' line, and locate above the ' $A$ ' line in the plasticity chart. Hence, The UCSC classification of BCS is $\mathrm{CH}$ (clay with high plasticity). In addition, BCSs are characterized by the high liquid limit and free swell index. The California bearing ratio (CBR) is measured at only $1.6 \%$, and far from the requirement of the roadbed fillings [12]. Below BCS layer, the soil is silty clay with a handful of decomposed rock. Standard penetration tests (SPTs) were performed on this soil layer, and the average SPT blow count for this layer was between 10 and 15. 
Tab. 1 - Properties of BCS

\begin{tabular}{lc}
\hline Parameters & Values \\
\hline Silt $(>2 \mu \mathrm{m})(\%)$ & $45-51$ \\
Clay $(<2 \mu \mathrm{m})(\%)$ & $49-55$ \\
Liquid limit (\%) & $68.5-73.8$ \\
Plastic limit (\%) & $34.2-42.7$ \\
Plasticity index (\%) & $31.6-37.2$ \\
Free swell index (\%) & $136-182$ \\
California bearing ratio (\%) & $1.3-2.1$ \\
\hline
\end{tabular}

\section{Formation of crack in highway embankment}

The highway embankment was constructed on BCS in numerous sections of the researched motorway. The top $80 \mathrm{~cm}$ of the foundation BCS was excavated and then back filled with gravel soil or the mixes of the scoria and clay. The fillings of the embankment are the nonexpansive clays with stiff consistency. The side slope of the highway embankment is $1.75(\mathrm{H}): 1(\mathrm{~V})$. The thin BCS layer closes the slope surface to resist the rainfall penetration. Unfortunately, the embankment in various sections cracked after a heavy rainy season. The cracks usually occurred on the low embankment located at areas with flat terrain, where the mixes of clay and scoria replaced BCSs in foundation. The cracks included lengthways cracks, transverse cracks and other linear cracks, and were characterized by the extreme breadth of about $3 \mathrm{~cm}$, and some of them even penetrate through the roadbed [7].

\section{EXPERIMENT AND SIMULATION}

\section{Sampling and testing}

BCSs were sampled from $\mathrm{km} 26+180$ in the existing highway connecting the capital Addis Ababa with Adama, where the embankment cracked after a heavy rainy season. The laboratory tests were performed on soil samples and highway embankment in Ethiopia. Those tests included moisture content of BCS, water permeability coefficient of fillings and deflection of the highway embankment. The moisture content of the disturbed soil samples at the different depth was measured in the laboratory. This investigation was to determine the moisture change in BCS below the replacement layer, which was a key reason for the embankment cracks. According to Chinese standards [13], the permeability tests were performed on the replacement materials by road seepage meter. The structural diagram of the road seepage meter is presented in Figure 1. Granular soil samples $(300 \times 300 \times 200 \mathrm{~mm})$ were compacted under a compactness of $93 \%$. The seepage meter was first fixed on the sample. Then the water was poured into the measuring cylinder. When the water dropped to the scale of $100 \mathrm{ml}$, the timer started. Every 60 seconds, water level was noted down till the scale of $500 \mathrm{ml}$. The water permeability coefficient is the quotient of water seepage divided by the needed time. Moreover, the deflection tests were performed on the top of the highway embankment near cracks using the Benkelman beam. 


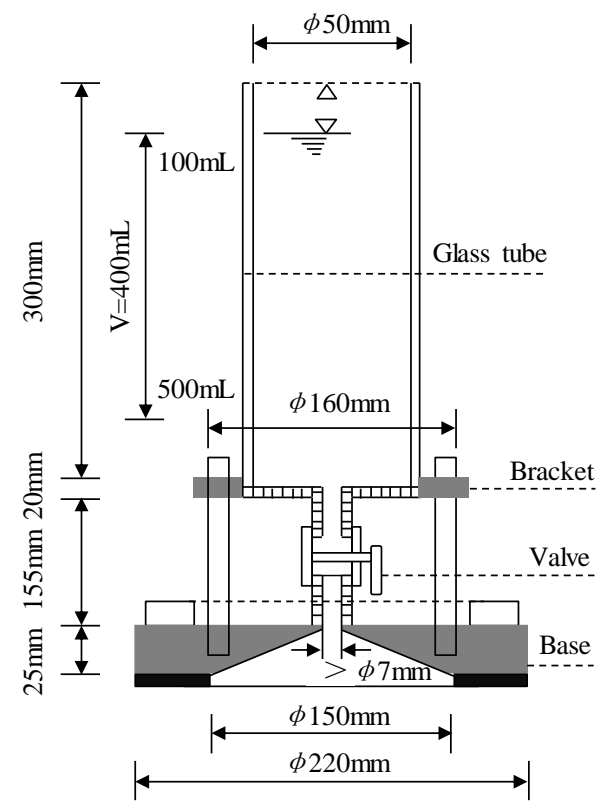

Fig. 1 - The structural diagram of road seepage meter

\section{Numerical analysis}

\section{Coupled consolidation theory for unsaturated soil}

The rainfall will cause the reduction in soil suction and result in the expansion of the clays. However, the following the drought events lead to the soil desiccation, the expansion of clays disappears and the shrinkage occurs [14]. The soil desiccation after a heavy rain may lead to shrinkage crack of the soil. Here BCS shrinkage due to water loss was simulated by Abaqus/Standard based on the coupled consolidation theory for unsaturated soil. The change in volume of clay as exposure to water is described by double-variables theory as follows [15].

$$
\begin{aligned}
& d \varepsilon_{v}=m_{1}^{s} d\left(\sigma_{m}-u_{a}\right)+m_{2}^{s} d\left(u_{a}-u_{w}\right) \\
& d \theta=m_{1}^{w} d\left(\sigma_{m}-u_{a}\right)+m_{2}^{w} d\left(u_{a}-u_{w}\right)
\end{aligned}
$$

where $d \varepsilon_{v}$ is the volumetric strain of the clays, $d \theta$ is the change in volumetric moisture content, $\sigma_{m}$ is the mean net normal stress, $u_{a}$ is the pore air pressure, $u_{w}$ is the pore water pressure, $\left(\sigma_{m}-u_{a}\right)$ is the mean normal stress, $\left(u_{a}-u_{w}\right)$ is the matric suction, $m_{1}^{s}$ is the compression coefficient related to the normal stress, $m_{2}^{s}$ is the compression coefficient related to the matric suction, $m_{1}^{w}$ is the coefficient of water change related to the normal stress, $m_{2}^{w}$ is the coefficient of water change related to the matric suction.

The void ratio and moisture content can be defined as follows, using the mean normal stress and matric suction.

$$
\begin{gathered}
e=f\left(\sigma_{m}-u_{a}, u_{a}-u_{w}\right) \\
W G_{s}=g\left(\sigma_{m}-u_{a}, u_{a}-u_{w}\right)
\end{gathered}
$$

where $e$ is the void ratio of the clay, $w$ is the moisture content, $G_{s}$ is the specific gravity of the clay, $f$ and $g$ are arbitrary functions. written as:

The volumetric strain and change in moisture content of the unsaturated soils can be 


$$
\begin{gathered}
d \varepsilon_{V}=\frac{\partial e}{\left(1+e_{0}\right) \partial\left(\sigma_{m}-u_{a}\right)} \Delta\left(\sigma_{m}-u_{a}\right)+\frac{\partial e}{\left(1+e_{0}\right) \partial\left(u_{a}-u_{w}\right)} \Delta\left(u_{a}-u_{w}\right) \\
d \theta=\frac{\partial w G_{s}}{\left(1+e_{0}\right) \partial\left(\sigma_{m}-u_{a}\right)} \Delta\left(\sigma_{m}-u_{a}\right)+\frac{\partial w G_{s}}{\left(1+e_{0}\right) \partial\left(u_{a}-u_{w}\right)} \Delta\left(u_{a}-u_{w}\right)
\end{gathered}
$$

The compression coefficient can be calculated by Eqs. (1), (2), (5) and (6).

$$
\begin{aligned}
& m_{1}^{s}=\frac{1}{1+e_{0}} \frac{\partial e}{\partial\left(\sigma_{m}-u_{a}\right)} \\
& m_{2}^{s}=\frac{1}{1+e_{0}} \frac{\partial e}{\partial\left(u_{a}-u_{w}\right)} \\
& m_{1}^{w}=\frac{G_{S}}{1+e_{0}} \frac{\partial w}{\partial\left(\sigma_{m}-u_{a}\right)} \\
& m_{2}^{w}=\frac{G_{S}}{1+e_{0}} \frac{\partial w}{\partial\left(u_{a}-u_{w}\right)}
\end{aligned}
$$

The water continuity equation of an unsaturated soil can be obtained by soil-water mass conversation if the water is assumed to be incompressible.

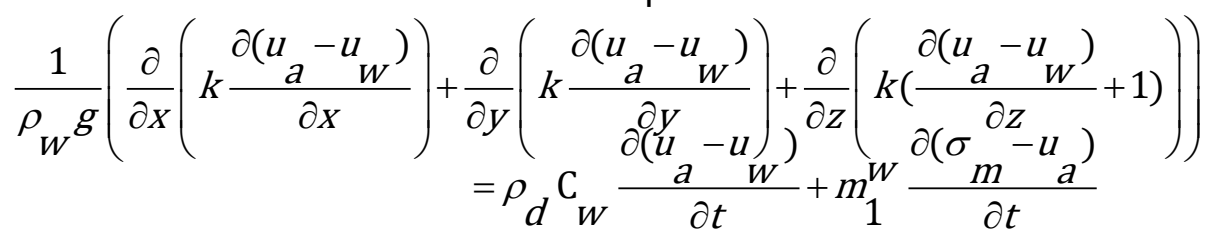

where $\rho_{w}$ is the density of water, $\rho_{d}$ is the dry density of the soil, $g$ is the acceleration of gravity, $k$ is the hydraulic conductivity, $C_{w}$ is the specific water capacity of the soil.

The laboratory tests were performed to construct the constitutive relation for unsaturated soil of BCS. Those tests include the specific gravity test, free shrink test, suction test and swellconsolidation test, which are determined by following standard methods[11]. Previous research listed the constitutive surface for unsaturated soil of BCS [16].

Falling head permeability tests were performed to obtain the saturated hydraulic conductivity of the subgrade soil. The soil-water characteristic curve (SWCC) describes the relationship between the suction and water content in soil and can be obtained by suction tests. With the help of SWCC, the unsaturated hydraulic conductivity versus matric suction was described by Van Genuchten, M model [17].

$$
k\left(u_{a}-u_{w}\right)=k_{s} \frac{\left\{1-\left|a\left(u_{a}-u_{w}\right)\right|^{n-1}\left[1+\left|a\left(u_{a}-u_{w}\right)\right|^{n}\right]^{-m}\right\}^{2}}{\left[1+\left|a\left(u_{a}-u_{w}\right)\right|^{n}\right]^{m / 2}}
$$

where $k\left(u_{a}-u_{w}\right)$ is the hydraulic conductivity; $k_{s}$ is the saturated hydraulic conductivity; $\left(u_{a}-u_{w}\right)$ is the matric suction; $a, n$ and $m$ are the fitting parameters, $m=1-1 / n$. The variation of hydraulic conductivity with matric suction for BCS is shown in Figure 2. 


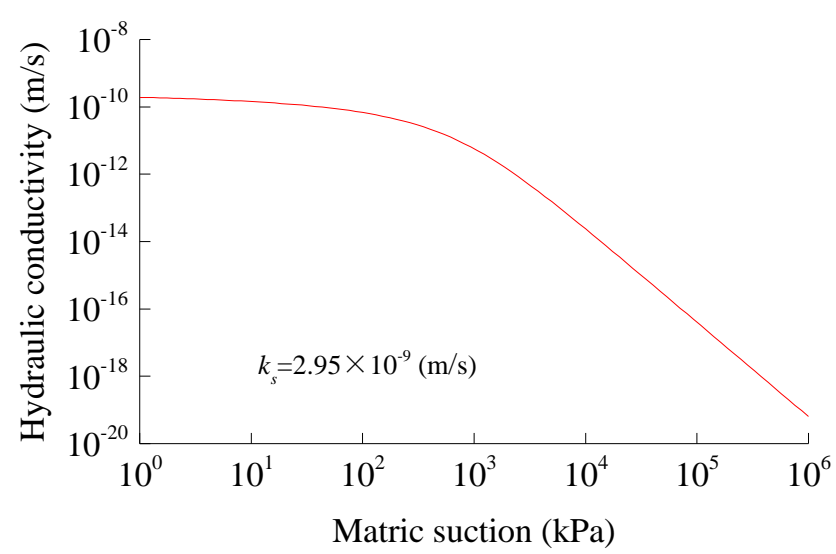

Fig. 2 - Variation of hydraulic conductivity with matric suction for BCS

\section{Numerical model}

The thermal mechanical coupling has the analogous differential equations with the hydromechanical coupling. In addition, Abaqus/standard provides the "coupled thermal stress analysis" option. Hence, coupled thermal stress analysis was performed to solve the coupled consolidation problem for unsaturated soil by Abaqus codes. The simulation performed a main program and four user subroutines such as USDFLD, UMAT, UMTHT and UEXPAN. The main program defines the mesh, initial conditions, boundary conditions and step. With the help of the FORTRAN, USDFLD read the net normal stress and matric suction of every nodes from the main program, and calculated the material parameters of the subgrade soils based on the constitutive relation for unsaturated soil, those material parameters included the elasticity modulus $(E)$, expansion coefficient (a), compression coefficients $\left(m_{1}^{s}, m_{2}^{s}, m_{1}^{w}, m_{2}^{w}\right)$ and unsaturated hydraulic conductivity $\left(K\left(u_{a}-u_{w}\right)\right)$. The parameters $K\left(u_{a}-u_{w}\right), m_{2}^{w}$ and the change in mean normal stress were inputted into UMTHT to calculate the unsaturated seepage. Elasticity modulus $E$ was inputted into UMAT to update the stiffness matrix. Expansion coefficient a was inputted into UEXPAN to calculate the change in the thermal stress.

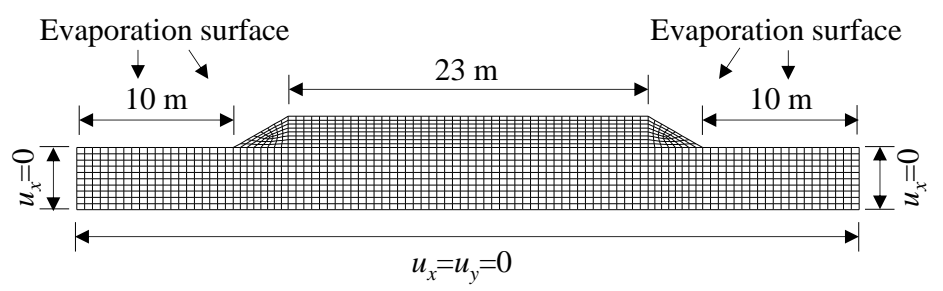

Fig. 3 - 2-D views of highway embankment section

The FEM of the highway embankment on BCS is presented in Figure 3 . The width of the crest was $23 \mathrm{~m}$. The side slope of the highway embankment was $1.75(\mathrm{H}): 1(\mathrm{~V})$. The element types CPE4T used in the simulation were continuum stress/displacement element with heat flux being allowed. The bottom nodes were restricted to move in all directions. The lateral nodes were restricted to move in $x$ direction. The slope and outside foundation constituted the evaporation surface. Moreover, unsaturated properties of the subgrade soil were not an option. The embankment weight was the only load in the simulation. The simulation started after a long-term rainy season, hence the initial suction of the subgrade is assumed to be $10 \mathrm{kPa}$, which is corresponding to the field capacity for most soil. 


\section{RESULT AND DISCUSSION}

\section{Moisture changes in foundation BCS}

BCSs below replacement base were excavated and air-dried during construction. Hence the moisture content in the soil sample for testing the degree of compaction was only $18.4 \%$. The moisture content in the BCS after a heavy rainy season is shown in Table 2 . The moisture content in BCS below replacement base increased in the rainy season until closed to the plastic limit and was in the range of $36-40 \%$. It was very close to the moisture content in BCS of beside farmland, which was in the range of $25.8-40.9 \%$. The findings indicated that the backfill soil was a material with a large permeability and allowed rainwater to permeate into BCS below replacement base.

Tab. 2 - Moisture content distributions in BCS located at K26+180

\begin{tabular}{lcccccccc}
\hline Foundation BCS depth (cm) & 10 & 20 & 30 & 40 & 50 & 60 & 70 & 80 \\
\hline Measured moisture content (\%) & 38.3 & 40.0 & 39.8 & 36.0 & 37.6 & 38.2 & 38.1 & 37.6 \\
Plastic limit (\%) & 38.2 & 39.9 & 38.9 & 38.4 & 38.9 & 38.4 & 39.7 & 39.0 \\
\hline Farmland BCS depth (cm) & 25 & 50 & 75 & 100 & 125 & 150 & 175 & 200 \\
\hline Measured moisture content (\%) & 25.8 & 38.2 & 40.1 & 38.8 & 40.2 & 40.0 & 40.9 & 40.9 \\
Plastic limit (\%) & 38.9 & 38.4 & 39.3 & 38.6 & 39.1 & 38.6 & 38.7 & 39.1 \\
\hline
\end{tabular}

a The bottom of the backfill foundation was the starting sample surface.

The materials backfilled the foundation trench included the gravel soil and the mixes of the clay and scoria. The particle distribution of those materials is presented in Figure 4. The scoria has the superiority of good gradation and high strength, is a high quality subgrade material. However, its high permeability allows the rainwater to permeate into BCS below replacement base. Hence the scoria was mixed with clays to backfill the foundation trench. Both materials should give play to their respective advantages in high strength and low permeability.

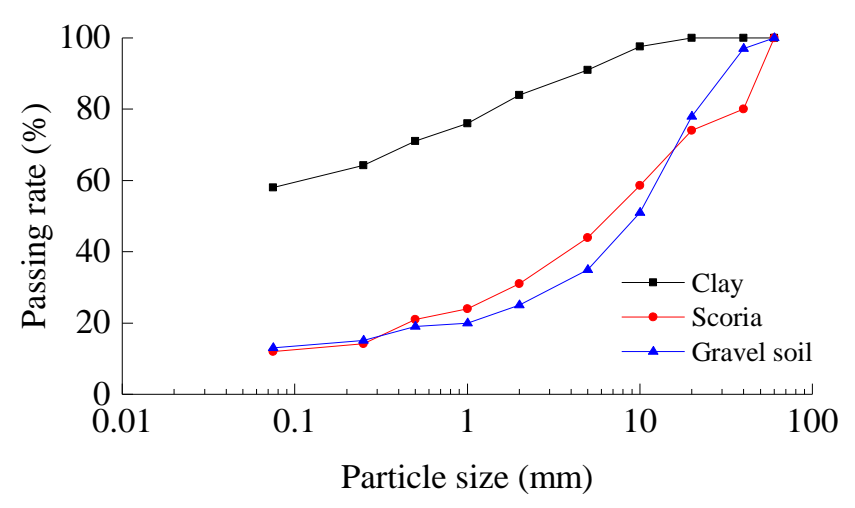

Fig. 4 - Particle distribution of materials to backfill foundation

Tab. 3 - Water permeability coefficient of fillings

\begin{tabular}{cc}
\hline Clay: scoria & Permeability \\
\hline $3: 1$ & 8 \\
$2: 1$ & 10 \\
$3: 2$ & 15 \\
$1: 1$ & 17 \\
$1: 2$ & 100 \\
$1: 3$ & 200 \\
Gravel soil & 7 \\
\hline
\end{tabular}


Unfortunately, the mixes of scoria with clay are still a material with the high permeability. The water permeability coefficient of the replacement materials is presented in Table 3 . The water permeability coefficient of the mixes decreased with the increase in the clay content. When the ratio of clay content to scoria content was $1: 3$, the water permeability coefficient of the mixes was $200 \mathrm{~mL} / \mathrm{min}$. Even if this ratio increased to $3: 1$, the water permeability coefficient of the mixes only decreased to $8 \mathrm{~mL} / \mathrm{min}$, which was close to the permeability of the gravel soil.

\begin{tabular}{|c|c|c|}
\hline ID & $\begin{array}{l}\text { Deflection }{ }^{\mathbf{b}} \\
(0.01 \mathrm{~mm})\end{array}$ & $\begin{array}{l}\text { Deflection }{ }^{\mathrm{c}} \\
(0.01 \mathrm{~mm})\end{array}$ \\
\hline km 19.500-19.900 & - & 173 \\
\hline km 25.980-26.180 & 129 & 178 \\
\hline km 40.000-40.550 & 139 & 146 \\
\hline $\mathrm{km} 40.550-41.000$ & 123 & 140 \\
\hline $\mathrm{km} 41.200-42.000$ & 109 & 179 \\
\hline
\end{tabular}

a The design deflection was $160 / 0.01 \mathrm{~mm}$.

Deflection of embankment (b) before rain and (c) after rain.

BCS Over-excavation and replacement with the scoria developed a catchment area below the subgrade base in the areas with flat terrain. When rainwater seeped into BCS through the replacement layer, BCS would expand and weaken the integral strength of the highway embankment. The measured deflections of highway embankment in some section are presented in Table 4. The mixes of clay and scoria replaced BCSs in the section of km 40-41, but subgrade drainage was smooth due to the large longitudinal gradient. The integral strength of highway embankment decreased little. The measured deflections also met the design requirement. Sections of $\mathrm{km} \mathrm{25.98-26.18}$ and $\mathrm{km} \mathrm{41.2-42} \mathrm{were} \mathrm{characterized} \mathrm{with} \mathrm{minor} \mathrm{gradient.} \mathrm{The} \mathrm{deflections} \mathrm{of} \mathrm{the}$ highway embankment increased tremendously due to the smooth drainage and cannot meet the requirement of the subgrade strength.

\section{Embankment crack due to BCS shrinkage}

The cracks were generally found on the highway embankment with a height of less than $1.75 \mathrm{~m}$. Hence, the embankment cracks are probably caused by BCS shrinkage linked to the evaporation and not the rainfall infiltration. The BCSs below replacement base swell as exposure to water in the rainy season, and undergo the water losing shrinkage in the following dry season, which causes the additional tensile stress within the highway embankment. When the tensile stress exceeds the ultimate tensile strength of the soil, the embankment cracks occur in the different style. Thus, our analysis focuses on the contribution of major principal stress and refers to the criterion provided by literature [18], in which the major principal stress for creation of subgrade crack is $10 \mathrm{kPa}$.

Figure 5 presents the deformation and stress distribution of highway embankment after BCS evaporation of 30 days. The evaporation intensity, embankment height and BCS thickness were fixed at $5 \times 10^{-8} \mathrm{~m} / \mathrm{s}, 2 \mathrm{~m}$ and $4 \mathrm{~m}$, respectively. The maximum soil movement took place at the slope and decreased gradually along the embankment width, and its value approximates to zero at the center of the road. The differential deformation developed the additional tensile stress in the highway embankment. The minimum crack depth took place at the center of the road and increased gradually along embankment width, and the cracks near the slope even penetrated through the highway embankment. 

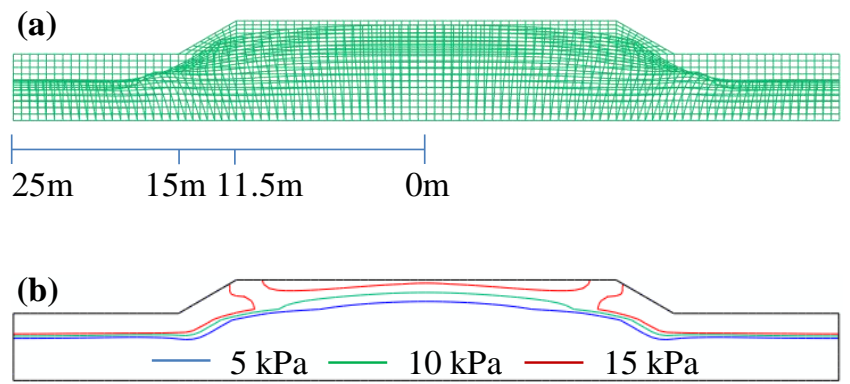

Fig. 5 - Deformation (a) and stress distribution (b) of highway embankment after BCS evaporation of 30 days

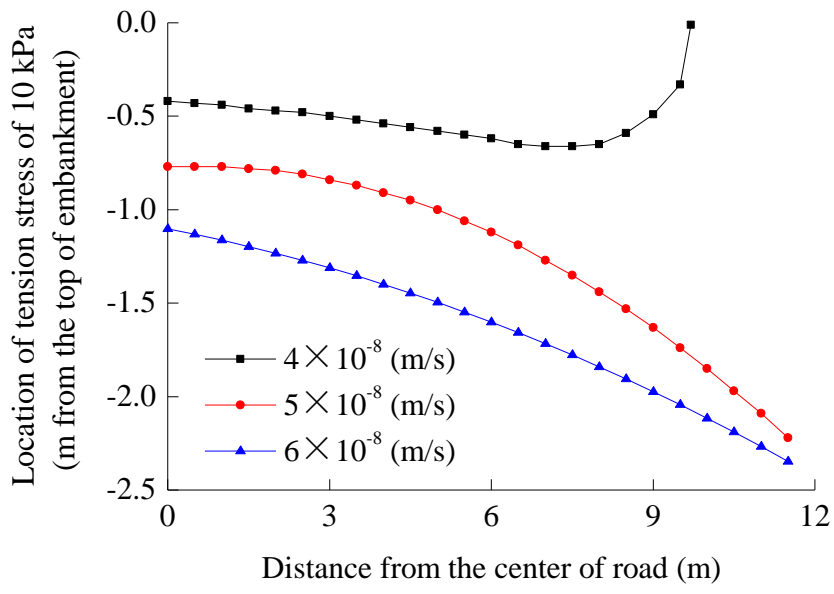

Fig. 6 - Influence of evaporation intensity on crack depth of highway embankment

The influence of evaporation intensity on crack depth of highway embankment is presented in Figure 6. Embankment height and BCS thickness were fixed at $2 \mathrm{~m}$ and $4 \mathrm{~m}$, respectively. The possible crack area and depth increased with the increase in evaporation intensity. After 30 days of soil evaporation, the cracks may occur at any location of the highway embankment under the evaporation intensity of $6 \times 10^{-8} \mathrm{~m} / \mathrm{s}$. The cracks even penetrated through the highway embankment at the sites near the road shoulder. When the evaporation intensity decreased to $4 \times 10^{-8} \mathrm{~m} / \mathrm{s}$, the cracks took place in the range of 0-9.7 $\mathrm{m}$, and the maximum depth was only about $0.5 \mathrm{~m}$.

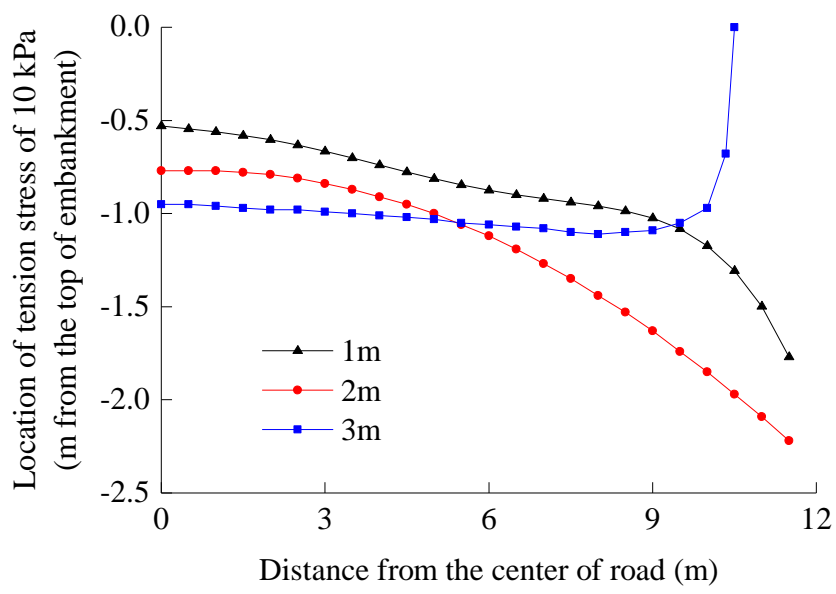

Fig. 7 - Influence of embankment height on crack depth of highway embankment 
The influence of embankment height on crack depth of highway embankment is presented in Figure 7. Evaporation intensity and BCS thickness were fixed at $5 \times 10^{-8} \mathrm{~m} / \mathrm{s}$ and $4 \mathrm{~m}$, respectively. The location of the tension stress at a value of $10 \mathrm{kPa}$ was closer to the bottom in the lower embankment. After 30 days of soil evaporation, the maximum crack of $1 \mathrm{~m}$ and $2 \mathrm{~m}$ high embankment penetrated through the highway embankment into the foundation, but the maximum crack depth of $3 \mathrm{~m}$ high embankment was only about $1.1 \mathrm{~m}$. The embankment weight will restrain the expansion of the foundation BCS as exposure to water. Hence the foundation BCS under the higher embankment has a relatively small shrinkage in the dry season. So the higher highway embankment developed the cracks with the smaller depth.

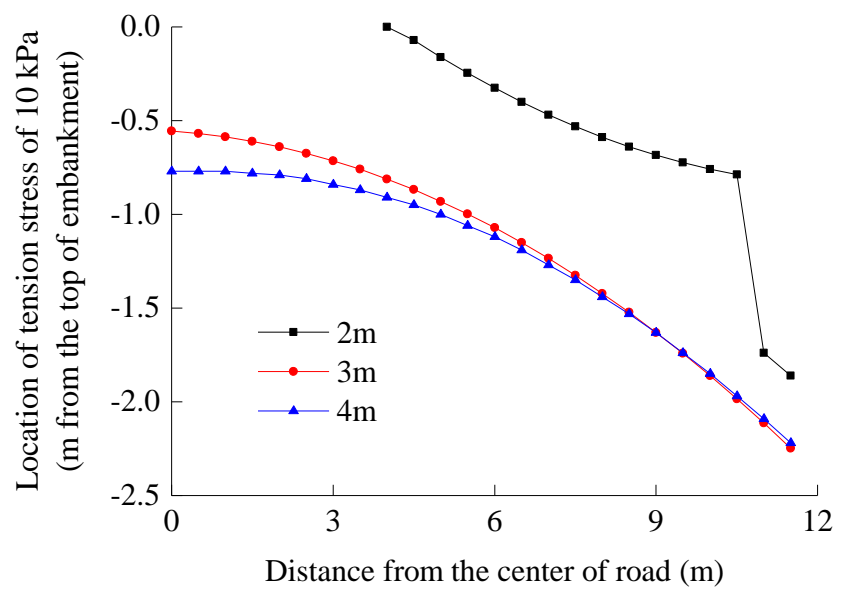

Fig. 8 - Influence of BCS depth on initial cracking of highway embankment

The influence of BCS thickness on crack depth of highway embankment is presented in Figure 8. The evaporation intensity and embankment height were fixed at $5 \times 10^{-8} \mathrm{~m} / \mathrm{s}$ and $2 \mathrm{~m}$, respectively. After 30 days of soil evaporation, the cracks were not found within the highway embankment on $1 \mathrm{~m}$ thick of BCS. When the thickness of BCS increased to $3 \mathrm{~m}$, cracks penetrated through the highway embankment. However, crack behaviour of highway embankment on $3 \mathrm{~m}$ and $4 \mathrm{~m}$ thick BCS had no obvious difference. This is attributed to the active zone of BCS, which is in the range of 1.8-2.6 $\mathrm{m}$ [6]. As the moisture content remains stable, BCS below the active zone has a minor influence on the upper highway embankment.

\section{CONCLUSIONS}

In this research, the crack generation within highway embankment was investigated. The water permeability coefficient of the replacement materials was tested in the laboratory to explain the change in moisture content of foundation BCS. The simulation was performed to investigate the tension stress of the embankment induced by the BCS shrinkage. The simulation took the wet status of subgrade after a heavy rainy season as a starting point. The following conclusions are drawn:

(1) The high permeability of the replacement base allowed rainwater to permeate into BCSs, and their water swelling leaded to the decrease in the subgrade strength.

(2) Water losing shrinkage of wet BCS induced the additional tension stress within highway embankment.

(3) The maximum crack depth took place at the position near the shoulder and decreased gradually along embankment width. Greater evaporation intensity, lower highway embankment and thicker layer of BCS induced the deeper cracks within highway embankment. 


\section{ACKNOWLEDGEMENTS}

This work has been funded by the National Natural Science Foundation of China (51804129, 51904112), the project of Jiangsu provincial Six Talent Peaks (JZ-011), the Open Fund of Guangxi Key Laboratory of Road Structure and Materials (2019gxjgclkf003), Jiangsu Planned Projects for Postdoctoral Research Funds (2020Z422), the open fund for Jiangsu Engineering Laboratory of Structure Assembly Technology on Urban and Rural Residence, Huaiyin Institute of Technology (JSZP201905), and the support from the "333 Project"funded by Jiangsu Province in 2020 (BRA2020221).

\section{REFERENCES}

[1] Yitagesu, F.A., van der Werff, H., van der Meer, F., Hecker, C., 2012. On the relationship between plasticity and spectral characteristics of swelling soils: The 3-5 $\mu \mathrm{m}$ wavelength region. Applied clay science, 69: 67-78.

[2] Ola, S.A., 1978. The geology and geotechnical properties of the black cotton soils of northeastern Nigeria. Eng. Geol, 12: 375-391.

[3] Ackroyd, L.W., 1986. Husain, R. Residual and lacustrine black cotton soils of northeast Nigeria. Geotechnique, 36(1): 13-18.

[4] Zhao, P., Xu, Z.X., Tang, L., Zeng, D.L., 2014. Research on the black cotton soil swell-shrink characteristics and the depth of black cotton soil influenced by the atmosphere in Ethiopia. Journal of Railway Engineering Society, 4: 46-50.

[5] Xu, Z.X., Tang, L., Zhang, K., He, X.J., Hou, W.L., 2014. Research on survey methods and engineering properties of black cotton soil of Ethiopian railway. Journal of Railway Engineering Society, 2: 15-18.

[6] Wang, X.Y., Yu, X.L., Song, H., Zhou, Y.D., 2017. Research on the replacement depth and treatment method of black cotton soil in Ethiopian. Highway, 3: 7-12.

[7] Wang, X.F., Wang, Y., Zhang, Y.H., 2012. Design for treatment of subgrade on black cotton soil (BCS). Highway, 9: 46-53.

[8] Gerard, P., Mpawenayo, R., Douzane, M., Debaste, F., 2016. Influence of climatic conditions on evaporation in soil samples. Environmental Geotechnics, 6(6): 323-333.

[9] Irmak, S., Irmak, A., Allen, R.G., Jones, J.W., 2003. Solar and net radiation-based equations to estimate reference evapotranspiration in humid climates. J Irrig Drain Eng, 129: 336-347.

[10] Cheng, Y.Z., Huang, X.M., Li, C., Shen Z.P., 2017. Field and numerical investigation of soilatmosphere interaction at Nairobi, Kenya. European Journal of Environmental and Civil Engineering, 21(11): 1326-1340.

[11] Research institute of highway ministry of transport., 2007. JTG E40-2007 Test Methods of Soils for Highway Engineering (China Communications Press) 415 PP.

[12] CCC first highway consultants co., LTD., 2015. JTG D30-2015 Specification for design of highway subgrades (China Communications Press), 220 PP.

[13] Research institute of highway ministry of transport., 2008. JTG E60-2008 Field test methods of subgrade and pavement for highway engineering (China Communications Press), 136 PP.

[14] Vardon, P.J., 2015. Climatic influence on geotechnical infrastructure: a review. Environmental Geotechnics, 2(3): 166-174.

[15] Fredlund, D.G., Morgenstern, N.R., 1976. Constitutive relations for volume change in unsaturated soils. Canadian Geotechnical Journal, 13(3): 261-276.

[16] Cheng, Y.Z., Huang, X.M., Li, C., Li, L.Y., 2017. Numerical analysis of crack generation within embankment built on expansive soil foundation. Journal of Southeast University (English Edition), 33(2): 224-229.

[17] Van Genuchten, M.T., 1980. A closed form equation for predicting the hydraulic conductivity of unsaturated soils. Soil Sci Soc Am J, 44: 892-898.

[18] Zheng, J.L., Yang, H.P., 2009. Expansive soil engineering of highway, 170-171 (China communications press) 268 PP. 